\title{
PATRIOTISME SUFISTIK IBN AL-TAYMTYYAH; KONSEP DAN KIPRAHNYA
}

\author{
Moch. Kalam Mollah' \\ IInstitut Teknologi Adhi Tama Surabaya
}

\begin{abstract}
ABSTRAK
Tulisan ini mengkaji pemikiran tokoh Muslim terkenal bernama Ibn al-Taymīyah. Sebagai seorang individu yang hidup di era masyarakat heterogen dan penuh pergolakan politik, tokoh kelahiran al-Harrān memiliki gagasan yang bisa dibilang unik dan berbeda dari para pendahulunya. Dengan mengkaji sumber pustaka yang relevan, penulis menemukan bahwa ide Ibn al- Taymiyah berbeda dengan mayoritas pemikiran yang telah ada sebelumnya. Baginya seorang pemimpin harus memiliki kecakapan, keterampilan, serta rasa keadilan dalam memimpin negara. Selain itu ia juga dikenal sebagai seorang seorang patriot yang telah mendedikasikan dirinya demi kepentingan bangsa dan negara. Di samping sebagai seorang cendekiawan sekaligus patriot dengan jiwa solidaritas kenegarawanannya, Ibn alTaymīyah juga dikenal sebagai salah seorang yang memiliki konsepsi sufistik yang begitu kuat. Konsep tersebut menekankan bahwa motivasi membela bangsa dan negara harus diimbangi dengan sikap zuhud dan ketulusan bahwa manusia adalah bagian dari entitas kemanusiaan yang tidak akan lepas dari aspek ketuhanan.

Kata Kunci: Patriotisme; Ahl al-Shawkah; Kepemimpinan, Negara.
\end{abstract}

\section{ABSTRACT}

This paper examines the thoughts of a famous Muslim figure named Ibn al-Taymīyah. As an individual who lives in an era of heterogeneous society and full of political upheaval, the figure born in al-Harrān has ideas that are arguably unique and different from his predecessors. By examining relevant literature sources, the writer finds that Ibn alTaymiyah's ideas differ from the majority of pre-existing thoughts. For him, a leader must have the skills, skills and a sense of justice in leading the country. In addition, he is also known as a patriot who has dedicated himself to the interests of the nation and state. Apart from being an intellectual as well as a patriot with a spirit of state solidarity, Ibn alTaymiyah was also known as one who had such a strong Sufistic conception. This concept emphasizes that the motivation to defend the nation and state must be balanced with zuhud and sincerity that humans are part of a human entity that cannot be separated from the theological aspect.

Keywords: Patriotism; Ahl al-Shawkah; Leadership, Country.

\section{A. Pendahuluan}

Ibn al-Taymīyah salah seorang cendekiawan Muslim yang terkenal di dunia Islam. la hidup pada puncak disintegrasi politik melanda Muslim. Lebih dari itu, terdapat sekian banyak persoalan yang membelit dunia Islam, seperti berkembangannya aneka ragam perdebatan dan lahirnya pelbagai budaya yang memicu munculnya tidak sedikit persoalan di waktu itu. Pelbagai fenomena yang tejadi di era itu, menumbuhkan keterpanggilan dalam diri seorang Ibn al-Taymīyah. Sebagai seorang cendekiawan ia merasa terpanggil untuk memberikan sumbangsihnya bagi 
keberlangsungan umat. ${ }^{1}$ Sebagai seorang tokoh yang dijuluki sebagai Aḥmad b. Hanbal muda, ia dikenal memiliki kualitas intelektual layaknya Aḥmad b. Hanbal. Kritiknya yang tegas dan cukup mengena terhadap kondisi masyarakat saat itu, khususnya yang berkenaan dengan beberapa pemahaman yang tidak relevan jika harus diterapkan di masa itu.

Tidak hanya melahirkan beberapa karya yang tidak sedikit menghadirkan pencerahan bagi umat sampai saat ini, bentuk pratriotismenya juga teruji dengan munculnya pelbagai cobaan dan tantangan dari dalam dan luar negeri Muslim. Gagasannya mengenai siyāsah shar'iyah menyatakan bahwa manusia adalah makhluk politik yang dibentuk dari alam, karena dengan alami ketika mereka menerapkan sebuah pemerintahan di situ ada tujuan dan manfaat, seperti pembentukan moral, tolong menolong dan gotong royong. Apa yang diintrodusir olehnya tampak sangat unit. ${ }^{2}$ Dalam persoalan pemimpin negara Ibn al-Taymīyah mengkritik keras pandangan Shī'ah tentang doktrin yang mengatakan kalau pemimpin dalam pengangkatannya diangkat oleh Tuhan. la juga tidak sependapat dengan pendapat mayoritas yang menghendaki pengangkatan pemimpin melalui proses pemilihan. Tidak kalah kontroversial, di bidang politik ia menyatakan kesetujuannya terhadap kepemimpinan orang non-Muslim atas kaum Muslim. Semua itu ia bangun anggapan bahwa bukan agama, ras, suku maupun bangsa yang menjadi syarat utama seorang pemimpin, melainkan kemampuan untuk menghadirkan kesejahteraan dan berlaku adil. ${ }^{3}$

Dengan latar belakang tersebut, artikel ini hadir guna mengelaborasi beberapa persoalan yang masih menyisakan pertanyaan. Di antaranya: bagaimana kondisi sosial yang sebenarnya hingga mampu mempengaruhi seorang Ibn al-Taymīyah untuk mencetuskan beberapa gagasannya? Benarkah ia merupakan seorang dengan jiwa patriotik tinggi? Ataukah sebaliknya bahwa sosok Ibn al-Taymīyah hanyalah seorang cendekiawan Muslim yang sangat kolot dalam pemikirannya? Seperti apa sebenarnya konsep kenegaraan khususnya kepemimpinan yang ditawarkan oleh Ibn alTaymīyah? Apakah benar bahwa gagasannya mirip dengan gagasan kenegaraan seorang Aristoteles? Apakah ia merupakan tokoh yang dengan serta merta selalu mengedepankan nass secara leksikal tanpa memandang kondisi sosial yang terjadi saat itu? Jawaban dari beberapa pertanyaan tersebut akan membuktikan apakah tulisan ini patut diapresiasi atau sebaliknya. Oleh karena itu, untuk memulai kajian ini penulis

\footnotetext{
${ }^{1}$ Lihat, Ibn al-Taymīyah, Majmu' Fatawā (Riyad: Matabi' Riyad, 1993).

${ }^{2}$ Ibn al-Taymīyah, Siyāsah Shar'iyah (Mesir: Darul al Kitabala Arabi, tt), 162.

${ }^{3}$ Ibn al-Taymīyah, Majmuk al-Rasāil al-Kubrā (Kairo: tp, 1996). 
rasa perlu kiranya untuk membukanya dengan kajian tentang latar belakang kehidupan Ibn al-Taymīyah.

\section{B. Perjalanan Hidup}

Taqī al-Dīn Abū al-Abbas Aḥmad 'Abd al-Halim b. al-Imām Majd al-Dīn Abī alBarakah 'Abd al-Salām b. Muḥammad al-Khựarī b. 'Abd Allāh b. Ibn al-Taymīyah adalah nama lengkap dari seorang cendekiawan Muslim yang dikenal sebagai Ibn alTaymīyah. la lahir di Harrān yang terletak antara sungai Dajalah (Tigris) dan Efrat, tepatnya pada hari Minggu tanggal 10 Rabi' al-Awwāl 661 Hijrīah bertepatan dengan 22 Januari $1263 .{ }^{4}$ la hidup di masa kerajaan Mamālik yang berkuasa atas Mesir dan Syuriah. Pada masa pemerintahan al-Zāhir Rukn al-Dīn Baybars tahun 658-676 H. (12601277 M.) hingga pertengahan masa pemerintahan Nāṣir al-Dīn Muḥammad tahun 709741 H. (1309-1340 M.). ${ }^{5}$

Tokoh kelahiran al-Harrān tersebut berasal dari keluarga zuhud, wara' dan terhormat. la dilahirkan dari seorang ayah bernama Shihab al-Dīn 'Abd al-Halīm b. 'Abd al-Salām seroang syekh, ahli al-Ḥadīth, mufassir, ahli ilmu ushul dan nahwu. ${ }^{6}$ Jika ayahnya cukup masyhur dikenal, ibu Ibn al-Taymīyah belum diketahui secara pasti dari mana ia berasal. Ada pendapat yang menyatakan bahwa ia berasal dari tanah Arab, ada pula yang menilai ia sebagai seorang Kurdi. Terlepas dari persoalan latar belakang ibunya, latar belakang keluarga Ibn al-Taymīyah yang berasal dari keturunan alim, ahli tafsir, al-Hadīth, ușūl al-fiqh, fiqh dan nahwu, telah mendorongnya menjadi seorang figur mujtahid mutlak. Selain kedua orang tuanya, ia memiliki kakek bernama Majj alDīn Abī al-Barakat 'Abd al-Salām b. 'Abd Allāh.' Pamannya adalah seorang cendekiawan muslim yang cukup populer dan seorang penulis yang produktif di masanya, al-Khātib Fakhr al-Dīn. Adik laki-lakinya yang bernama 'Abd Allāh b. 'Abd alHalīm merupakan seorang ilmuan Muslim yang cukup masyhur sebagai ahli dalam bidang ilmu kewarisan Islam, al-Ḥadīth dan juga dalam ilmu eksakta. ${ }^{8}$

\footnotetext{
${ }^{4}$ Siti Mahmudah Noorhayati, “Exclusive Islam From the Perspective of Ibn. al-Taymīyah”, Esensia: Jurnal IlmuIlmu Ushuluddin, vol. 18 no. 2 (Oktober, 2017), 214. Mul Irawan, “Mekanisme Pasar Islami dalam Konteks Idealita dan Realita: Studi Analisis Pemikiran al-Ghazali dan Ibnu Taimiyah), Jurnal Ekonomi dan Bisnis Islam, vol. 1 no. 1 (Januari, 2015), 71.

5 Abu Tholib Khalik, "Pemimpin Non-Muslim dalam Persapektif Ibnu Taimiyah”, Analisis: Jurnal Studi Keislaman, vol. 14 no. 1 (Juni 2014), 69.

${ }^{6}$ Yasin, "Pemikiran Hukum Islam Ibnu Taimiyah”, Jurnal Ilmlah Al-Syir'ah, vol. 8 no. 2 (Desember, 2010 ), 439.

7 Noor Ma'ruf, "Studi Analisis Pemikiran Ibn Taimiyyah Tentang Konsep Jihad" (Skripsi-- IAIN Walisongo, Semarang, 2010), iii.

8 Ibid., iv.
} 
Dalam perjalanan hidupnya, Ibn Taymīyah tampaknya dihadapkan dengan kenyataan yang cukup pelik, ia diharuskan untuk meninggalkan al-Harrān yang merupakan kampung halamannya bersama ayah dan ketiga saudaranya ke Damaskus. Ini terjadi sebagai dampak terjadinya invasi yang dilakukan Mongol ke dalam wilayah al-Harrān. Seusai berpindah ke Damaskus, ayahnya menjadi kepala sekolah sebuah madrasah yang bernama Madrasah Sukkarīyah. Di madarasah tersebut Ibn al-Taymīyah kecil menempuh pendidikan formal. Di sana ia diajar oleh seorang guru yang bernama Shams al-Dīn 'Abd al-Rahmān al-Makdīsī. al-Makdīsī adalah seorang cendekiawan penganut mazhab Hanbalī setelah reformasi Baybars. Ibn al-Taymīyah kemudian menggantikan posisi ayahnya sebagai kepada madrasah hingga pada tanggal 2 Muharrram 683 H. (21 Maret 1284 M.) ia diperbolehkan untuk mengajar yang pertama kalinya. Pada tanggal 10 Safar 684 atau 17 April 1285 dia mulai mengajar tentang tafsir al-Qur'ān di Masjid Umayyad. ${ }^{9}$

Berdasarkan tulisan berjudul Pemimpin Non-Muslim dalam Perspektif Ibnu Taimiyah yang ditulis oleh Abu Tholib Khalik yang juga mengutip Syafiq A. Mughni dalam bukunya yang berjudul Dinamika Intelektual Islam Pada Abad Kegelapan dinyatakan bahwa Ibn al-Taymīyah adalah orang yang sangat disegani pada saat itu dan dianggap sebagai keturunan Imam besar Ahmad b. Hanbal dan juga mendapat julukan sebagai Ahmad muda. Dijuluki seperti itu karena penguasaan intelektual Ibn alTaymīyah dinilai setara dengan Aḥmad b. Hanbal. ${ }^{10}$ Selain itu ia juga dikenal sebagai pemikir yang kritis, mandiri, setia dengan kebenaran, hebat dalam berpidato dan memiliki keuletan yang luar biasa hebat. ${ }^{11}$ Pada sekitaran tanggal 20 Dzulhijjah $728 \mathrm{H}$. (26 September $1328 \mathrm{M}$ ) dia wafat di suatu penjara dan dikebumikan pada waktu Ashar di samping makam Syekh Jamāl al-Islām Sharaf al-Dīn. ${ }^{12}$

\section{Negara dalam Pandangan Ibn Taymīyah}

Diketahui bahwa Ibn al-Taymīyah dalam pemikiranya tentang sebuah negara, memiliki kesamaan dengan pemikiran negara dari filsuf Yunani Klasik semacam Aristoteles. Kesamaan itu bisa dilihat dari pemikiran keduanya yang pada intinya memandang negara sebagai suatu kebutuhan di mana seorang pemimpin wajib ada

\footnotetext{
${ }^{9}$ Noorhayati, “Exclusive Islam”, 214-215.

10 Khalik, "Pemimpin Non-Muslim", 68-69.

11 Anton Afrizal Candra, "Pemikiran Siyasah Syar'iyah Ibnu Taimiyah: Kajian terhadap Konsep Imam dan Khilafah dalam Sistem Pemerintahan Islam”, Universitas Islam Rlau Press Journal, vol. 1 no. 2 (Oktober, 2017), 164.

12 Irawan, “Mekanisme Pasar Islami”, 71.
} 
guna mengatur jalannya negara dan kesejahteraan bersama. ${ }^{13}$ Disebutkan juga bahwa manusia itu merupakan makhluk politik yang dibentuk dari alam, dengan demikian secara alami ketika mereka menerapkan sebuah pemerintahan disitu ada tujuan dan manfaat yang ingin diperoleh, seperti pembentukan moral, tolong menolong dan juga gotong royong. ${ }^{14}$

Dalam pandangannya, Ibn al-Taymīyah untuk kewajiban mendirikan sebuah negara atau kekuasaan. Ibn al-Taymīyah menjelaskan bahwa untuk mewujudkan negara yang dapat mensejahterakan umat di dunia akhirat, maka diperlukannya seorang pemimpin negara yang adil dan rakyat yang patuh akan pemimpinnya. Dalam hal ini ia menggunakan karakteristik al-Hadīth dan juga ajaran Islam. Oleh karena itu tidak berlebihan kalau disebut bahwa gagasan Ibn al-Taymīyah mengenai pendirian suatu negara harus mendasarkan pada kewajiban agama. Meskipun demikian, sekali lagi la menolak konsep suatu negara harus dibentuk karena pertimbangan ijmā', melainkan kewajiban untuk mensejaterakan umat. ${ }^{15} \mathrm{Jadi}$, ide pemerintahan suatu negara dalam perspektif ini tidak lain adalah satu gagasan tentang negara harus berdasar nilai-nilai Islam dengan tujuannya untuk memenuhi kebutuhan umat di alam semesta ini. ${ }^{16}$

Dalam kehidupan berpolitik, sebagai seorang cendekiawan di sini Ibn alTaymīyah sangat menekankan akan pentingnya suatu negara untuk memiliki seorang pemimpin yang amanah dan adil. Kriteria tersebut dinilai sangat berhubungan berperan besar dalam melahirkan suatu negara yang baik. Jika seorang pemimpin memimpin secara amanah, maka secara tidak langsung ia telah menjalankan kewajibannya secara adil begitu pula sebaliknya. Oleh karena itu, ia tidak mensyaratkan bagi seorang pemimpin harus menjadi Muslim. Karena sesungguhnya terdapat firman Allāh di surat al-Nisā' menjelaskan tentang suruhan seseorang untuk menyampaikan sebuah amanah kepada mereka yang berhak dan melaksanakan keadilan dalam menetapkan sebuah hukum untuk manusia. Di sini ditekankan bahwa perlunya pemimpin yang penuh dengan keterampilan dan kecakapan dan bukan karena adanya sebuah ikatan primordial. ${ }^{17}$ Meskipun demikian dalam perkembangannya gagasan ini mendapatkan banyak kritikan dari cendekiawan Muslim lainnya.

\footnotetext{
13 Candra, "Pemikiran Siyasah”, 164.

14 Ibid., 164-165.

15 Ibid., 166-167.

16 Ibid.

17 Ibid., 167.
} 
Terlepas dari perdebatan syarat seorang pemimpin apakah harus seorang Muslim, Tuhan mewajibkan hamba-Nya untuk patuh kepada Allāh, Rasul dan juga dengan pemimpin. Firman tersebut berada di surat al-Nisā' ayat 59. Maksud dari firman tersebut adalah mematuhi pemimpin yang tidak melanggar ketentuanketentuan dalam Islam dalam menjalankan pemerintahannya selain mematuhi Allāh serta Rasul. Dia menjelaskan bahwa untuk menyelesaikan suatu perkara yang ada di lingkungan masyarakat luas, diperlukan suatu sikap yang adil dan mendasarkan pada hukum yang berkaitan dengan persoalan yang dihadapi. Para pemimpin juga dituntut untuk membudayakan musyarawah guna menyelesaikan suatu persoalan. Musyawarah diperlukan sebagai wahana yang bertujuan untuk menyelesaikan suatu masalah dan sebagai bentuk perbuatan yang menggambarkan sikap orang yang beriman. ${ }^{18}$

Dalam pandangan Ibn al-Taymīyah pemimpin terdiri dari pemimpin negara dan ulama, hal tersebut didasarkan pada surat al-Nisā' ayat 59. Karena itu jika ingin mewujudkan masyarakat yang baik, maka harus terjadi kerjasama antara pemimpin negara dan para ulama. Kerjasama yang terjalin pun harus berdasarkan kepentingan dan atas pedoman al-Qur'ān serta al-Ḥadīth. Jika seorang pemimpin mengalami kesukaran dalam mencari dalil-dalil, maka ia dapat menuruti orang yang memiliki pengetahuan agama yang lebih dan juga terpercaya. Dalam persoalan ini Ibn alTaymīyah menekankan pentingnya kemampuan dalam berijtihad. ${ }^{19}$ Ijtihad dilakukan guna memurnikan agama dari pemikiran-pemikiran sesat. Sampai di sini penulis menangkap bahwa dalam pandangan Ibn al-Taymīyah, tujuan dan peran negara itu menegakkan agama demi kepentingan rakyat yang sejahteraserta demi keselamatan hak dan kewajiban warganya.

Jika gagasan Ibn al-Taymīyah dibawa ke dalam konsep sekarang ini, maka kurang lebih ia akan menyatakan bahwa berkelompok guna mengelola kapasitas alam merupakan suatu keharusan. Hal ini akan mendorong lahirnya suatu institusi yang disebut negara. Sebab bernegara merupakan suatu gagasan organis yang tidak mungkin dihindari. Menurutnya, penting bagi suatu institusi untuk melakukan pengelolaan masyarakat guna mencapai apa yang dinamai sebagai keadilan. Manusia pada dasarnya memiliki watak suka membangun secara alami. Karena alasan itulah setiap kali mereka berkumpul dan berkelompok pasti mengusahakan suatu kegiatan yang dibutuhkan untuk kemaslahatan dan mengatasi persoalan yang ada pada diri mereka. Ibn alTaymīyah sendiri memandang bahwa hakikat pemerintahan yaitu kekuasaan yang

\footnotetext{
18 Ibid., 168.

${ }^{19}$ Fazlur Rahman, Islam, terj. Senoaji Saleh (Jakarta: Bumi Aksara, 1992), 113. 
memaksa juga diperlukan jika ingin adanya suatu solidaritas dalam masyarakat dan jika tidak ingin hancur dalam keegoisan alamiah manusia.

Allāh memiliki kedudukan sebagai satu-satunya Dhāt yang memiliki kekuasaan dan kekuatan. Di bumi, khalifah ditugaskan untuk membentuk pemerintahan yang adil. Setelah wafatnya Rasul, Allāh menguji manusia untuk segera memilih pengganti pemimpin sebagai seorang khalifah. Ibn al-Taymīyah menjelaskan bahwa pemerintahan Islam itu sebagai, bayangan Allāh di muka bumi. la menjelaskan tentang pentingnya kekuasaan dalam menegakkan syariat serta kewajiban umat untuk mematuhinya. Dia memandang Islam sebagai suatu ajaran sekaligus tatanan sosial yang dapat dijadikan sebagai inspirasi kehidupan manusia. ${ }^{20}$

Ibn al-Taymīyah mengkritik keras gagasan Shī'ah tentang ajaran mereka yang mengatakan kalau Imam itu dalam pengangkatannya harus diangkat oleh Allāh seperti 'Alī yang diangkat oleh Tuhan dan yang telah dibuktikan oleh ijmā'. la juga tidak sependapat dengan kaum Sunni dalam pengangkatan pemimpin yang dilaksanakan dengan jalan pemilihan. Ibn al-Taymīyah dalam pendapatnya menegaskan bahwa pengangkatan kepala negara harus dilakukan dengan model pengangkatan alKhulafā' al-Rāshidīn. Dalam pengangkatannya keempat khalifah tersebut menggunakan adanya mubāya'ah (pembaiatan) dalam persetujuan umat, yaitu sumpah kesetiaan antara imam atau kepala negara dan juga masyarakat dalam mengadakan suatu kerja sama, yang disebut bernegara. Hal ini oleh cendekiawan asal Harrān tersebut dianggap sebagai suatu cerminan dari keinginan taat kepada Allāh serta Rasul-Nya. ${ }^{21}$

Kepala negara menurut Ibn al-Taymīyah memiliki kewajiban untuk meneliti dengan teliti siapa saja yang akan menduduki kekuasaan di daerah-daerah, dari tingkat yang terendah hingga ketingkat atas. Dalam pengangkatannya pun harus bersikap adil tidak berdasarkan hubungan saudara, sahabat, suku, daerah maupun sebab lainnya, tapi harus berdasarkan kecakapan serta keterampilan untuk menjadi seorang pemimpin. Untuk orang yang menempati jabatan tersebut haruslah orang yang memang memiliki hak dan juga adil. Jika pemimpin yang baik tersebut menjalankan amanah rakyat dengan baik maka orang tersebut akan dipandang Allāh sebagai pemimpin yang baik tidak hanya dipandang baik oleh rakyatnya. Pengankatan

${ }^{20}$ Imron Mustofa, "Fisika Atom sebagai Basis Filosofis Ilmu dalam Perspektif al-Ghazali." Epistemé: Jurnal Pengembangan Ilmu Keislaman 12, no. 1 (2017), 53-75.

${ }^{21}$ Candra, "Pemikiran Siyasah", 170. 
pemimpin menurut dia dipandang sebagai cara pengangkatan yang baik karena objektif dan aktual. ${ }^{22}$

Dalam Islam yang secara jelas menyuruh untuk penegakan dalam amar ma'rūf nahy 'an munkar, penegakan keadilan, bermasyarakat secara teratur, menolong orang yang dianiaya, melaksanakan hukum hadd, kesemuanya itu hanya akan terwujud bila ada pemimpin atau penguasa. Dalam hal ini perlu adanya seorang pemimpin agar dapat terwujud cita-cita tersebut. Dari semua apa yang telah dimaksud olehnya, sudah jelas bahwa pemimpin itu merupakan wali, agen otoritas, wakil Tuhan untuk mengatur umat. Dapat ditekankan dari penjelasan tersebut bahwa seorang pemimpin bukanlah seorang yang memiliki suatu negara melainkan orang yang melaksankan perintah Allāh demi kelangsungan hidup manusia. Ibn al-Taymīyah sendiri dengan gamblang menyatakan bahwa negara adalah amanah atau mandat Tuhan kepada sang pemimpin untuk dipelihara dengan baik. ${ }^{23}$

Ibn al-Taymīyah sendiri tidak pernah menyinggung suatu sistem yang bertujuan untuk pengangkatan pemimpin. Namun, jika diamati dan dipahami lagi, meskipun dia tidak menetapkan suatu sistem khusus untuk itu tetapi yang tepenting baginya bahwa orang yang akan memimpin harus amanah dan adil. la lebih mementingkan persyaratan ini bagi seorang pemimpin dibanding hal lainnya. Ini dikarenakan melalui persyaratan yang cocok, maka orang tersebut dapat duduk di kursi pemerintahan dengan sistem apa saja. Dalam persyaratan seorang kepala negara, dalam perspektif Ibn al-Taymīyah, harus memenuhi persyaratan kekuatan dan integritas. Dari kedua hal tersebut apa yang dimaksudnya adalah orang yang kuat untuk dipercaya dan orang yang baik untuk bekerja. Persyaratan tersebut serupa dengan apa yang termaktub dalam surat alQashash ayat 26.

Ibn al-Taymīyah tidak mengharuskan ataupun menetapkan satu bentuk suatu negara. la lebih menghendaki bentuk suatu negara didasarkan pada kemaslahatan masyarakat secara luas. Bentuk suatu negara harus didasarkan pada kerjasama antar masyarakat serta didasarkan pada nilai-nilai syariat dalam Islam, karena sejatinya penguasa dari segala penguasa adalah Allāh. Apa yang dikehendaki Ibn al-Taymīyah sebagai negara setidaknya dapat kita rangkum di antaranya: pertama negara hukum. Bentuk negara semacam ini adalah bentuk negara yang mendasarkan segala sesuatu pada hukum, baik hukum Ilahi ataupun nazarī. la sebenarnya lebih menghendaki jika negara hukum itu lebih dominan kepada hukum Ilahi dengan segala syariat yang ada,

\footnotetext{
22 Ibid. 171.

${ }^{23}$ Khalik, “Pemimpin Non-Muslim”, 78. 
namun di sisi lain ia juga tidak menolak tentang hukum-hukum yang dibuat oleh para penguasa. Meskipun demikian ia mensyaratkan bagi hukum yang disebut terakhir harus berdasarkan al-Qur'ān dan al-Sunnah, dalam arti tidak melenceng. Kedua, ia menghendaki bentuk negara republik. Bentuk negara ini mengajarkan bahwa dalam penentuan kepala negara, calon pemimpin berasal dari rakyat dan juga rakyat lah yang harus memilihnya. Ketiga, ia juga menghendaki negara monarki. Bentuk negara ini dipimpin oleh seseorang yang memiliki keunggulan daripada masyarakat lain yang menjadikanya dipilih menjadi pemimpin karena kepercayaan warganya. Namun, sang pemimpin tersebut harus menujukan tugas kepemimpinannya hanya untuk Allāh. Dari pernyataan-pernyataan tersebut sebenarnya Ibn al-Taymīyah tidak menetapkan secara pasti bentuk negara apa yang baik, namun ia hanya memberi opsi-opsi bentuk negara, dan yang terpenting suatu bentuk negara tersebut hanya bertujuan untuk Allāh dan keadilan rakyat. ${ }^{24}$

Ibn al-Taymīyah menjadikan al-Qur'ān sebagai suatu landasan atas segala ideidenya. la berpatokan bahwa ajaran Islam adalah ajaran yang mengandung nilai-nilai kebenaran. Oleh karena itu, keadilan harus ada bahkan menjadi suatu kebaikan bagi seluruh alam. Dalam berpolitik dan kenagaraan, la sangat menekankan bahwa keadilan yang universal adalah sesuatu yang jauh lebih baik daripada tingkat keimanan seseorang. Kemudian atas pemikirannya tersebut keluarlah ungkapan yang cukup kontroversial di kalangan cendekiawan Muslim, yaitu "lebih baik jika dipimpin oleh orang non-Muslim yang adil daripada orang Muslim yang zalim". ${ }^{25}$ Dalam pernyataan tersebut jelas bahwa untuk menjadi seorang pemimpin tidak memandang orang tersebut agama apa, ras apa atau dari tradisi apa ia dibesarkan, namun dari keadilan seorang pemimpin tersebut. Tugas utama negara sebagai negara yaitu tegaknya keadilan yang universal tanpa memandang apapun. Meskipun demikian yang tidak boleh dilupakan bahwa semua keadilan yang dilakukan harus berdasar hukum dan nilainilai dalam Islam.

Ibn al-Taymīyah memang hidup di daerah yang heterogen, karena ia hidup di zaman di mana perselisihan sedang gencar-gencarnya terjadi di lingkungan sekitarnya. Ibn al-Taymīyah hidup berdampingan dengan orang-orang yang berbeda agama, ras, suku, tradisi, serta bangsa. Baginya itu semua adalah suatu rahmat dan anugerah, karena itu dapat menimbulkan keberagaman. Jika keberagaman itu tidak

24 Taefur Aziz, “Bentuk Negara Menurut Ibnu Taimiyah”, (Skripsi--Universitas Negeri Sunan Kalijaga, Yogyakarta, 2008), 130-131.

${ }^{25}$ Khalik, “Pemimpin Non-Muslim”, 72-73. 
diorganisasikan dengan baik maka akan menjadi suatu persoalan tersendiri. Masalah itu datang karena masing-masing individu merasa saling benar, egois serta tidak mau mengalah satu sama lainnya. Jika dalam situasi yang tidak bagus seperti itu, maka akan memunculkan kesulitan dalam menciptakan stabilitas politik dan kehidupan sosial.

Tokoh kelahiran al-Harrā ini tampaknya tidak sependapat dengan konsep kekhalifahan kaum Quraysh. Baginya kepemimpinan Quraysh dinilai tidak relevan dengan fenomena yang terjadi saat ini yang telah diwarnai oleh konsep bernegara dengan lingkungan masyarakat yang heterogen serta hidup di era kosmopolitan. Baginya dalam kondisi masyarakat yang heterogen, setiap individu mempunyai hak dan kewajiban yang setara dalam persoalan kepemimpinan, baik sebagai yang dipimpin maupun pemimpin. la menolak untuk sependapat dengan ke-hujjah-an al-Hadīth yang menyatakan bahwa pemimpin harus dari kaum Quraysh. Kebanyakan pemahaman para cendekiawan Muslim tentang al-Hadīth tersebut dinilainya cenderung menyeru kepada pengkultusan suatu golongan, dalam konteks dewasa ini bisa pula dimaknai sebagai pengagungan satu bangsa tertentu. Menurut pendapatnya, ungkapan Rasul sejatinya tidak menyeru pada pengagungan satu golongan tertentu di atas yang lain. Sebab, seandainya itu terjadi maka akan terjadi kontradiksi antara pernyataan Nabi dan ayat dalam al-Qur'ān. la melihat di dalam al-Qur'ān selalu ditekankan akan pentingnya ketiadaan perbedaan antara satu individu dan lainnya, meskipun ada beberapa manusia yang memang dimuliakan di atas yang lain, seperti Nabi dan Rasul. la berpendapat bahwa persyaratan bagi seorang pemimpin itu berdasarkan al-Qur'ān karena memang lebih adil dan lebih bermakna. Gagasan ini ia tawarkan dengan alasan persoalan kepemimpinan sudah seharusnya mampu memberi solusi politik yang terbaik pada setiap lini masa kehidupan, karena kepemimpinan dalam ajaran Islam sudah selalu menekankan pada pemberian kesempatan yang sama rata dan adil. ${ }^{26}$

Mengenai persoalan non-Muslim, dari berbagai pernyataan yang dinyatakan oleh Ibn al-Taymīyah jelas bahwa menurutnya diperbolehkan bagi seorang Muslim untuk dipimpin oleh orang non-Muslim. Persoalan diperbolehkannya hal tersebut karena menurutnya yang terpenting dari seorang pemimpin adalah pemenuhan kualifikasi atau persyaratan kepemimpinan. Dalam kaca mata nya, persyaratan seorang pemimpin yang baik adalah yang akan menjadi kunci suksesnya suatu negara. Jika dikembalikan sedikit pada penjelasan sebelumnya, Ibn al-Taymīyah memang menegaskan bahwa selama

26 Ibid., 75. 
seorang pemimpin non-Muslim itu memenuhi persyaratan maka sah saja baginya untuk menjadi seorang pemimpin di kalangan masyarakat Muslim. Fenomena yang terjadi, kaum Muslim pun terkadang ada yang tidak bersikap adil, oleh karena itu ia memperbolehkan hal ini. Intinya, ia tidak mendahulukan seorang pemimpin karena latar belakangnya, melainkan integritas, kapasitas, komitmen, serta kemampuan yang dibutuhkan. ${ }^{27}$ Selain hal tersebut, dalam jurnal yang ditulis oleh Mufid, yang berjudul Ibnu Taimiyah dan Teori Pemerintahan Islam menjelaskan bahwa bentuk khilafah kaum Sunni yang dianggap memiliki landasan teologis dalam al-Qur'ān juga mendapat kritikan dari tokoh ini. la menyatakan bahwa kualitas negara Islam itu tidak terletak pada keselarasan dengan struktur konstitusional tertentu, melainkan adanya kecakapan serta kapasitas pemegang kekuasaan untuk melaksanakan prinsip syariah yang merujuk pada al-Qur’ān , al-Sunnah, ijmā' maupun qiyās. ${ }^{28}$

\section{Ahl al-Shawkah}

Ibn al-Taymīyah mensinyalir bahwa dalam proses pengambilan suatu keputusan sering kali terjadi adanya satu usaha monopoli dengan menolak adanya segala bentuk konsultasi dan lebih mengedepankan egoisme diri. Dalam hal ini bahkan Ibn alTaymīyah sempat mengkritik lembaga pengambil keputusan yang disebut Ahl Hall wa al-'Aqd. Menurutnya lembaga tersebut sering memproduksi suatu keputusan yang sama sekali tidak memihak kepada rakyat, bahkan tidak sedikit yang malah merugikan mereka. Dengan alasan ini ia menganggap para pejabat negara di lembaga itu sering kali hanya melaksanakan perintah penguasa tanpa mempertimbangkan kemaslahatan rakyat secara luas. la juga menilai bahwa lembaga semacam ini telah secara tidak langsung mempraktikan penegasian terhadap prinsip-prinsip shūrā dalam Islam. Melihat kenyataan semacam ini, Ibn al-Taymīyah menilai bahwa seharusnya lembaga tersebut melibatkan semua lapisan masyarakat dengan diwakili oleh dewan yang disebut Ahl al-Shawkah, dengan prinsip ketaatan tanpa memandang profesi, maupun kedudukan yang ada. ${ }^{29}$

Ijmā' dalam perspektif Ibn al-Taymīyah merupakan proses yang mendorong para ulama untuk melakukan pengambilan keputusan dengan cara musyawarah guna mendapatkan keputusan yang bulat dan final. Oleh karena itu, ia membagi ijmā

27 Ibid., 83-84.

${ }^{28}$ Mufid, “Ibnu Taimiyah dan Teori Pemerintahan Islam”, Jurnal Bestari, no. 13 (Nopember-Desember,1992), 21.

29 Shobahussurur, “Proses Pengambilan Keputusan Prespektif Ibn Taimiyah”, Jurnal Tsaqafah, vol.6, no.1 (April, 2010), 66-67. 


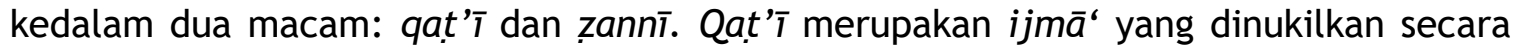
mutawātir baik ucapan atau perbuatan, atau dengan kata lain, yang sudah dipastikan tidak ada yang menyalahi dan keberadaannya disandarkan kepada nașs al-Qur'ān dan al-Ḥadīth. Ijmā' zannī merupakan ijmā' yang belum atau tidak dapat dipastikan bahwa di sana ada kemungkinan pendapat lain yang menyalahi ijmā' itu. ljmā' seperti itu sering juga disebut dengan ijmā' iqrārī atau istiqra ${ }^{‘} \bar{\imath}^{30}$

Oleh karena inti dari konsep bernegara adalah kesejahteraan rakyat, maka seharusnya mereka saling berkonsultasi demi menemukan jalan keluar yang terbaik, tanpa mengorbankan salah satu pihak. Sudah seharusnya rakyat juga berhak dalam menyampaikan aspirasinya. Aspirasi rakyat juga harus diindahkan oleh penguasa, selama itu memang baik untuk kebersamaan dan keutuhan sebuah negara. Jika melakukan suatu keputusan yang secara sepihak sudah jelas bahwa itu merupakan suatu kezaliman, maka kezaliman tersebut akan menjadikan suatu negara rusak, sebagai akibat dari sistem pemerintahan yang telah terinfeksi virus-virus dari pihak berwenang itu sendiri. ${ }^{31}$ Pemimpin negara selain menerima pendapat dari para ulama, harus menerima pendapat wakil-wakil rakyat yang mempunyai otoritas dari semua kelas-kelas masyarakat yang berkepentingan serta dari seluruh masyarakat yang sanggup memberikan pendapat. ${ }^{32}$

Ibn al-Taymīyah memberi persyaratan yang cukup ketat dalam menerima suatu hasil ijmā' sebagai dasar hukum. Persyaratan itu adalah adanya persetujuan secara penuh oleh seluruh ulama tentang ijmā' yang telah dilakukan serta. Dalam pandangan Ibn al-Taymīyah al-fuqahā' al-Arba'ah hanya merupakan kesepakatan yang mengikat dan bukan ijmā' final dengan kesepakatan seluruh kaum Muslim. la juga menyatakan bahwa ada batasan untuk keputusan-keputusan yang diambil ahl alshawkah dalam suatu musyawarah. Ada juga masalah-masalah yang tidak dapat diputuskan melalui konsultasi. Masalah-masalah tersebut di antaranya adalah masalah yang memang keberadaanya sudah jelas terdapat di dalam al-Qur'ān dan al-Sunnah. Hal tersebut terjadi karena keduanya merupakan dasar umat Islam yang tidak bisa dirubah. Namun jika itu bukan merupakan ajaran dasar, maka perlu dilakukan shūrā. ${ }^{33}$

Al-Qur'ān dan al-Sunnah tidak menetapkan satu bentuk sistem ketatanegaraan tertentu, keduanya hanya menyampaikan prinsip-prinsip dasar yang

\footnotetext{
30 lbid., 68.

31 lbid., 67.

32 lbid., 69.

33 Ibid., 68-69. 
harus dipegang teguh dalam kehidupan bermasyarakat dan bernegara. Ibn Taimīyah dalam gagasannya tentang negara menyatakan bahwa keberadaan negara dibutuhkan oleh umat secara rasional dan agama. Dalam penentuan pemimpin, bentuk dan konstitusi negara itu harus ditentukan oleh hasil konsultasi (musyawarah) umat sebagai pemegang kedaulatan. Di sini diperlukan keputusan-keputusan yang berdasarkan prinsip shūrā yang diperlukan untuk menata permasalahan-permasalahan yang ada dalam kehidupan rakyat. Ini karena konstitusi negara harus berdasarkan syari'at yang meliputi ajaran-ajaran dasar. Di sinilah peran dari keberadaan ulama, sebagai pemandu jalannya kehidupan berbangsa dan negara. ${ }^{34}$

Dari beberapa hal yang sudah dijelaskan di atas dapat disimpulkan bahwa untuk mengambil suatu keputusan maka dibutuhkannya mekanisme yang benar. Dari semua itu, yang terpenting adalah kualitas yang dimiliki sang pengambil keputusan. Hal lain yang mempengaruhi pengambilan keputusan yang baik adalah pengambil keputusan harus mampu merepresentasikan pandangan seluruh rakyat, keputusan itu harus diambil melalui mekanisme ijmā'. Ibn al-Taymīyah menyatakan selain keputusan diambil dari suara mayoritas, keputusan juga harus berpedoman pada al-Qur'ān dan alSunnah. Selain itu, bagi Ibn al-Taymīyah bagaimana cara untuk bermusyawarah yang baik tergantung dari prosesnya. Proses tersebut harus dimulai dengan pendekatan setiap masalah yang dimusyawarahkan harus berdasar al-Qur'ān dan al-Sunnah. Jika pendapat itu mendekati keduanya maka itulah yang dipakai atau yang digunakan. Di sini ada larangan tentang mengikuti suatu pendapat berdasarkan jabatan, ras, maupun golongan tertentu. Artinya jika sang pemberi pendapatan jabatannya tinggi tanpa menggunakan kedua pedoman di atas, maka pendapatnya tidak boleh diterima. Dengan kata lain, apa yang ingin disampaikan adalah dalam musyawarah tidak boleh hanya berdasarkan keputusan mayoritas rakyat melainkan dipertimbangkan juga dengan dua landasan penting dalam Islam. Jika keputusan itu tidak sesuai dengan kedua pedoman hidup agama Islam, maka tidak akan dilakukan. Jadi sistem musyawarah yang digagas di sini lebih mementingkan keputusan mayoritas dengan tetap melihat unsur-unsur kebaikan atau burukan sesuai agama.

34 Ibid., 69. 


\section{E. Penanaman Nilai-nilai Patriotisme}

Ibn al-Taymīyah mengarahkan segenap kemampuan yang dicurahkan untuk sesuatu yang dicintai Allāh serta menolak segala yang dibenci oleh Allāh. la menekankan pentingnya berjuang untuk menegakkan dan mempertahankan agama, juga dalam bidang pengembangan keilmuan. Bahkan dalam sejarah hidupnya, ia pernah ditawan karena berurusan dengan penguasa pada sekitaran tahun $1294 \mathrm{M}$. Menurutnya, agama dan negara tidak dapat dipisahkan, seperti bagian dari suatu kata dengan makna yang sama namun berbeda ejaan. ${ }^{35}$ Dalam sekian banyak karyanya, terdapat salah satu karya yang membahas politik yaitu al-Siyāsah al-Shar'īyah fī lslāt al-Ra'y wa al-Ra'Tiyah. Tulisan tersebut membincangkan signifikansi kekuasaan guna mewujudkan tujuan agama serta kewajiban umat untuk mematuhi penguasa selama mereka tidak memerintahkan kepada kemaksiatan. ${ }^{36}$ Karya lain yang membahas dasardasar hukum berjudul Jawāb fī ljmā' wa al-Khabar al-Mutawattir. Tulisan yang disebut terakhir membahas metode dalam pengambilan keputusan hukum yang sesuai nașs serta $i j m \bar{a} \cdot{ }^{37}$

Ibn al-Taymīyah pernah berurusan dengan penguasa kekaisaran Mamālīk saat berusia 32 tahun karena menghasut rakyat. Di Damaskus ia memimpin protes atas khatib Kristen dengan tuduhan menghina Nabi, hingga sang khatib dapat dihukum. ${ }^{38}$ Sekitar tahun 1298 M. ia pernah menyampaikan pendapat tentang sifat-sifat yang dimiliki Allāh. Pendapatnya itu dianggap bertentangan dengan keyakinan mayoritas ulama yang memerintah di Damaskus dan Kairo saat itu. Kemudian pada tahun 1305 M. ia dibawa ke Kairo untuk ditahan. Para penguasa saat itu mengumumkan untuk siapa saja yang membela Ibn al-Taymīyah, maka akan dihukum mati. Dia dipenjara di Kairo sekitar satu setengah tahun. ${ }^{39}$ Setelah itu ia kembali dipenjara karena digugat oleh para tokoh sufi di Kairo. la dianggap telah mengutuk pemahaman para sufi yang menganut ajaran ittihād, karena hal itu, ia ditahan di istana yang berlokasi di Alexandria. Dia dipenjara selama dua tahun lamanya di situ. Ibn al-Taymīyah kemudian dibebaskan oleh sultan al-Mālik al-Nāșir. Tiga tahun di negeri itu tokoh kelahiran Harrā tersebut mengisi harinya dengan menulis dan mengajar. ${ }^{40}$

35 Ibn al-Taymīyah, Al-Siyāsah al-Syar'īyah fī Ișlat al-Ra'y wa al-Ra‘īyah (Bayrūt: Dār al-Kutub al-'Ilmīyah, 1988), 138.

${ }^{36}$ Ibid., xiii.

37 Imron Mustofa, "Gagasan Islamisasi Ilmu (Studi tentang Kerangka Metodologi Institute for the Study of Islamic Thought and Civilization (INSISTS))". Disertasi-UIN Sunan Ampel, Surabaya, 2018, 200-201.

${ }^{38}$ Ma'ruf, "Studi Analisis Pemikiran", ix.

39 Ibid., xi.

${ }^{40}$ Ma'ruf, "Studi Analisis Pemikiran", xi. 
Syria kemudian menjadi tempat tujuannya pada tahun $1312 \mathrm{M}$. Di sana ia memimpin masyarakat untuk tidak mengecam pemerintah sampai pada tahun $1318 \mathrm{M}$. Karena ia menyampaikan fatwa-fatwa tentang masalah talak, sultan al-Mālik al-Nāṣir melarangnya untuk menyampaikan fatwa tersebut. Para anggota dewan sengaja dikumpulkan untuk membahas dan memutuskan tentang masalah ini. Ibn al-Taymīyah akhirnya dijebloskan ke penjara karena tidak mematuhi perintah Sultan. Setelah enam bulan dia bebas, namun masalah tersebut masih tidak kunjung reda. Para anggota dewan masih menyebarkan fitnah kepada sang tokoh. la akhirnya dipenjarakan kembali. Pada tanggal 26 September 1328 M. di penjara tersebut dia wafat pada usia 67 tahun. ${ }^{41}$

Menurut Hamka dalam karyanya Tasauf Perkembangan dan Pemurniannya ada perbedaan pandangan hidup antara al-Ghazālī dan Ibn al-Taymīyah. Hamka menjabarkan perbedaan antara sikap kedua tokoh tersebut. Pertama ia menggambarkan sikap al-Ghazāli ketika lingkungan sekitarnya terjadi perang salib, ia seolah tenggelam dalam khalwatnya. la memang dikenal sebagai seorang sufi yang seolah menolak hidup, takut akan menempuh hidup dan mengasingkan diri. ${ }^{42}$

Ibn al-Taymīyah pernah melawan raja Ghazan. Raja tersebut merupakan penguasa keturunan ketiga dari Gengis Khan. Raja tersebut menyerang Damaskus, padahal diketahui bahwa ia telah masuk Islam Ibn al-Taymīyah yang telah menetap lama di Damaskus ikut serta mempertahankan negeri itu. Ketika sang penguasa tersebut menginjakkan kaki di Damaskus, ia datang sebagai anggota delegasi mengahadap sang raja dan menegur sang raja atas apa yang dilakukannya. ${ }^{43}$

Selain dikenal sebagai seorang cendekiawan, Ibn al-Taymīyah juga merupakan seorang sufi yang zuhud guna mencapai kebesaran jiwa menentang segala penderitaan hidup. Bahkan menurut Hamka dalam bukunya Tasauf Perkembangan dan Pemurniaanya, Ibn al-Taymīyah digambarkan sebagai seseorang yang bertasawuf sejati. Tokoh kelahiran Harrān ini berpandangan bahwa seorang sufi ialah seorang yang dengan keras menegakkan sebuah kebenaran. Atas dasar inilah tidak mengherankan kalau Ibn al-Taymīyah saat negaranya dalam bahaya serangan musuh, ikut masuk kebarisan tentara pembela kebenaran, sesuai dengan perintah komando. ${ }^{44}$

\footnotetext{
41 Ibid., ixi-ixii.

42 Hamka, Tasauf, Perkembangan dan Pemurniannya (Jakarta: Citra Serumpun Padi, 1994), 215.

43 Ibid.

44 Ibid., 216-217.
} 
Ibn al-Taymīyah adalah seorang sufi yang dengan tegas ikut menentang musuh. Musuh bukan hanya negara lain yang mencoba menginvasi, tetapi penguasa yang tidak adil juga termasuk di dalamnya. Karena usahanya tersebut ia berkali-kali keluar masuk dan berganti-ganti penjara. Ibn al-Taymīyah pernah menyatakan pada murid yang dipenjara bersamanya, Ibn al-Qayyim bahwa dengan dipenjaranya ia, maka ia dapat mengembara dengan terus mencari kebenaran utamanya jika ia dipenjara di luar kampung halamannya. la juga bangga akan dirinya yang dipenjara karena masih teguh dalam mempertahankan keyakinannya. Selain itu, ia juga pernah mengatakan pada muridnya bahwa jika orang terbelenggu oleh hawa nafsunya maka orang tersebut sejatinya sedang ditawan oleh setan dan iblis. ${ }^{45}$

Seperti telah dibahas sebelumnya, seluruh gagasan Ibn al-Taymīyah mengenai sistem perpolitikan, ketatanegaraan, patriotisme kepemimpinan kesemua itu dipengaruhi oleh lingkungan sosio-politik yang terjadi di sekitarnya waktu itu. Dalam sejarah ia tercatat hidup di masa Mesir dipimpin oleh sultan al-Mālik al-Manșur Lajjin sekitaran tahun 696-698 H. (1297-1299 M.), sultan al-Mālik al-Nāṣir Muhammad b. alMansur al-Qalawun tahun 698-708 H. (1299-1308 M.) dan juga pada pemerintahan sultan al-Malik al-Muzaffar al-Baybars al-Jashankir tahun 709 H. (1309 M.). Di masa kekuasaan nama-nama tersebut dunia perpolitikan umat Muslim tengah mengalami pelbagai gejolak kekuasaan utamanya yang berkaitan dengan wilayah otonom yang sama sekali tidak berhubungan dengan kekuasaan kepemimpinan di Baghdād. Diketahui pada masa itu Ibn al-Taymīyah sebagai salah satu perintis tentang arti pentingnya pembeharuan hukum Islam. Dengan kata lain, ia merupakan salah satu aktor pertama yang menentang persoalan taqlīd meskipun secara diam-diam tetap mengikuti para pemimpin mazhab fikih. ${ }^{46}$

Ibn al-Taymīyah diyakini telah menjalankan tugas “memperbaharui syari’ah dan mempertahankan nilai-nilai agama”. Saat berusia 20 tahun ia diangkat menjadi muftī dan menghasilkan beberapa karya tulis maupun orasi-orasi keagamaan. Dia dengan pemikirannya menyarankan sebuah gerakan pemurnian reformatif yang dinamis dan menawarkan pemaknaan dalam persoalan agama dan sosial melalui perdebatan secara kritis serta menolak pemurniaan yang sempit dan cenderung dibatasi oleh fanatisme. Pernyataan-pernyataan dia saat itu cukup kontroversial dan banyak menimbulkan respons yang bermacam-macam dari umat Islam. Salah satu kritik pedas yang dialamatkan kepadanya yang menyatakan bahwa Ibn al-Batūtā pernah menilai

\footnotetext{
45 Ibid., 217.

${ }^{46}$ Ma'ruf, "Studi Analisis Pemikiran”, xvi.
} 
bahwa Ibn al-Taymīyah merupakan seorang individu berpengetahuan luas namun eksentrik dan terserang penyakit jiwa kronis. ${ }^{47}$ Tentu analisis semacam ini masih sangat mungkin dibantah, namun apa yang penulis dapati setidaknya menggambarkan bagaimana situasi dan kondisi yang dihadapi Ibn al-Taymīyah dalam menjalankan dakwahnya.

Terlepas dari itu, Ibn al-Taymīyah pernah ikut serta ke dalam politik praktis yaitu pada sekitaran tahun $693 \mathrm{H}$. (1293 M.). Saat itu ia ditengarahi telah melakukan suatu usaha intervensi atas penjatuhan hukuman kepada 'Assaf al-Nasrānī, seorang seorang umat Kristen yang dijatuhi hukuman mati oleh kaum Muslimin di daerah tersebut dikarenakan melakukan penghinaan terhadap Rasul. Gubernur Syria memberi pilihan kepada terdakwa, dihukum mati atau memeluk agama Islam. Terdakwa pun akhirnya memilih untuk menjadi seorang muallaf dan Gubernur kemudian memaafkan perbuatan tersebut. Ibn al-Taymīyah menentang keputusan tersebut, baginya jika ada seseorang baik umat Muslim maupun non-Muslim menghina nabi harus dijatuhi hukuman mati. Dalam pendapatnya meskipun seseorang masuk dan memeluk Islam tidak menghilangkan sebuah hukuman atas tindakan yang telah diperbuat. Karena pernyataannya yang dianggap menentang pemerintahan tersebut, dia akhirnya dipenjarakan, di penjaranya 'Adrawīyah yang terletak di Damaskus. Di sana dia menulis kitab yang berjudul al-șārim al-maslūl 'alā shātim al-Rasūl. Kitab tersebut merupakan salah satu karya fenomenal yang dihasilkannya. ${ }^{48}$

Salah satu peran penting dia tampak saat jasanya benar-benar dibutuhkan di era pemerintahan sultan al-Mālik al-Manșūr. la ditunjuk untuk memobilisasi penduduk guna mendesak umat Muslim melawan kerajaan Armenia kecil. Peran tersebut diemban Ibn al-Taymīyah karena ia dikenal sebagai sosok yang tegas, berwibawa dan pemberani. Setelah banyak mengalami bermacam peristiwa dalam hidupnya, ia kemudian memutuskan untuk fokus pada aktivitas menulis. Semua ini terbukti dengan lahirnya beberapa karya dia seperti al-Risālah al-Hamawīyah. Di dalam karya tersebut terdapat fatwa yang menjelaskan tentang sifat-sifat Allāh. Karya ini pula uang kemudian memaksanya untuk terlibat konflik dengan para fuqahā' yang saat itu dipimpin oleh al-Qāḍi Jalāl al-Dīn yang bermazhab Ḥanafīyah. Karena masalah tersebut pula dia akhirnya dibawa ke para ahli hukum dan juga hakim yang terkenal untuk dimintai keterangan atas pemikiran-pemikirannya yang terdapat pada risalahnya.

\footnotetext{
47 Ibid., xvii.

${ }^{48}$ Ma'ruf, "Studi Analisis Pemikiran", xvi.

48 Ibid., xvii.
} 
Keputusan terakhir dari sidang tersebut menyatakan Ibn al-Taymīyah memenangkan perdebatan dan menguatkan pendapatnya. ${ }^{49}$

Terlepas dari persoalan tersebut, keadaan politik Syiria pada waktu itu memaksanya untuk sementara waktu menghentikan kegiatan intelektual dan dakwah keagamaannya. la kemudian beralih ke politik praktis dengan menjadi orator dan agiator. Hal tersebut dilakukan untuk menggalang bantuan guna menghalau para tentara Mongol yang bersenjatakan modern. Pada tahun 700 H. (1301 M.), dia pergi ke Mesir tepatnya Kairo untuk meminta bantuan kepada al-Mālik al-Nāșir Muhammad b. al-Manșūr al-Qalawun. al-Qalawun merupakan salah seorang yang memimpin dinasti Mamālīk. Ibn al-Taymīyah pergi menemui sultan al-Qalawun guna memintanya agar mengirimkan pasukan ke Syiria sebagai bantuan umat Muslim di sana. Ibn al-Taymīyah yang memang berjiwa seorang pejuang dan berdarah militer kemudian dijadikan sebagai komandan pasukan tersebut. Pasukan yang dipimpinnya tersebut berhasil meraih kemenangan pada peristiwa Saqhab. Dengan tercapainya keberhasilan tersebut membuat nama Ibn al-Taymīyah semakin terkenal. Karena kemenangan tersebut juga dia dapat membujuk pihak militer untuk memberantas kaum “Assasin” yang diketahui adalah para pengikut Aḥmadīyah dan Kisrawanīyah. ${ }^{50}$

Perjalannya hidup Ibn al-Taymīyah tidak begitu saja menjadi mulus, ia bahkan mendapat tudingan dari rivalnya yang menyatakan bahwa dirinya merupakan seorang antrophomorpist. Tuduhan ini disebabkan karena dirinya menulis satu karya yang berjudul al-Hamīdīyā. Karya tersebut berisi pembelaan terhadap pendapat Aḥmad Ibn Hanbal. Selain itu ia juga menulis karya yang berjudul al-Risālah al-Wasitīyah yang sebenarnya bertujuan untuk pembelaan atas dirinya. Namun kenyataannya karya tersebut malah dinilai telah menegaskan dan memperkuat tudingan yang diterimanya. Atas banyaknya reaksi yang secara keras didapatkan membuat dia dipenjara. Dia dipenjara tanpa adanya proses peradilan terlebih dahulu. Namun, berkat uluran tangan Husam al-Dīn Mahna b. 'Isa, seorang Amir Arab, pada tahun 707 H. (1306 M.) Ibn al-Taymīyah dibebaskan dari penjara Kairo. ${ }^{51}$

Karyanya yang berjudul Waḥdah al-Wujūd juga mendapat reaksi keras dari kaum yang didalangi oleh Ibn 'Ata' al-Sakandarī. Reaksi keras tersebut juga diketahui didukung penuh oleh sultan al-Mālik al-Muzaffar Baybars al-Jashankir yang merupakan sultan pengganti al-Nāșir b. al-Qalawun. Karya tersebut memang berisi tentang

49 Ibid., xix.

50 lbid., xix-xx.

${ }^{51}$ Ma'ruf, "Studi Analisis Pemikiran", xx. 
kritikan terhadap ajaran tawașụl dan istighāthah. Terlepas dari itu, Ibn al-Taymīyah juga dipercaya oleh pemerintah Mesir untuk mengikuti perang di Yerussalem, Palestina. Saat itu dia berusia 51 tahun dan pada bulan Dhulqa'dah tahun $712 \mathrm{H}$. (Februari 1313 M.). Setelah itu, dia diperbolehkan untuk kembali ke Damaskus dan di sana dia mendapatkan sebuah gelar guru besar dalam bidang fikih dan dikukuhkan sebagai mujtahid mutlak. Ternyata karena kedatangannya ke Damaskus, membuat para rival politik Ibn al-Taymīyah kembali membuatnya mendekam di penjara. Namun, dia sudah seperti kebiasaan ketika dipenjara selalu berkarya dengan ide-ide yang cemerlang. Akibat dari itu juga dia menjadi dipersempit jalannya untuk berkarya. Peralatan berkaryanya untuk menulis dirampas secara paksa. la terpukul, karena ia tidak dapat menyumbangkan dan menyalurkan gagasan-gagasannya lagi. Setelah dua puluh hari ia tidak berkarya, dia meninggal karena jatuh sakit dipenjara pada usia 65 tahun. Dia meninggal pada hari Senin, 20 Dzulqa'dah 728 H. (26 September 1328 M.).

\section{F. Kesimpulan}

Sebagai penutup, artikel ini menyimpulkan bahwa: Pertama, kondisi masyarakat di mana Ibn Taymīyah merupakan masyarakat yang dipenuhi pelbagai macam problematika. Persoalan-persoalan tersebut cukup pelik yang meliputi pemikiran, nasionalisme dan gerakan-gerakan adat masyarakat. Kedua, Pemimpin yang ideal merupakan kolaborasi dari pemimpin negara dan ulama. Ketiga, konsep "jihad” dapat dapat dihadirkan dalam bentuk "kontak fisik" melawan penjajah dan dalam konteks pengembangan keilmuan. Penulis berargumen bahwa, mengulas Ibn Taymīyah ibarat menguras sumur tua. Keluasan pemikiran dan dinamika sosial-politik menjadikannya sebagai tokoh yang harus dikaji dalam berbagai sudut pandang. Dalam hal patriotisme, landasan sufistiknya memberi refleksi bahwa motivasi membela bangsa dan negara harus diimbangi dengan sikap zuhud dan ketulusan bahwa manusia adalah bagian dari entitas kemanusiaan yang tidak akan lepas dari aspek ketuhanan.

\section{G. Referensi}

Aziz, Taefur. “Bentuk Negara Menurut Ibnu Taimiyah”. Skripsi--Universitas Negeri Sunan Kalijaga, Yogyakarta, 2008.

Candra, Anton Afrizal. "Pemikiran Siyasah Syar'iyah Ibnu Taimiyah: Kajian terhadap Konsep Imam dan Khilafah dalam Sistem Pemerintahan Islam", Universitas Islam Rlau Press Journal, vol. 1 no. 2. Oktober, 2017. 
Hamka, Tasauf, Perkembangan dan Pemurniannya. Jakarta: Citra Serumpun Padi, 1994.

Ibn al-Taymīyah. Al-Siyāsah al-Syar'īyah fī lșlat al-Ra'y wa al-Ra‘īyah. Bayrūt: Dār alKutub al-'Ilmìyah, 1988. . Majm ü Fatawā. Riyad: Matabi' Riyad, 1993. .Majmü al-Rasāil al-Kubrā. Kairo: tp, 1996.

Irawan, Mul. "Mekanisme Pasar Islami dalam Konteks Idealita dan Realita: Studi Analisis Pemikiran al-Ghazali dan Ibnu Taimiyah), Jurnal Ekonomi dan Bisnis Islam, vol. 1 no. 1. Januari, 2015.

Khalik, Abu Tholib. "Pemimpin Non-Muslim dalam Persapektif Ibnu Taimiyah", Analisis: Jurnal Studi Keislaman, vol. 14 no. 1. Juni 2014.

Ma'ruf, Noor. "Studi Analisis Pemikiran Ibn Taimiyyah Tentang Konsep Jihad". Skripsi-IAIN Walisongo, Semarang, 2010.

Mufid, “Ibnu Taimiyah dan Teori Pemerintahan Islam”, Jurnal Bestari, no. 13. Nopember-Desember, 1992.

Mustofa, Imron. "Gagasan Islamisasi Ilmu (Studi tentang Kerangka Metodologi Institute for the Study of Islamic Thought and Civilization (INSISTS))". Disertasi-UIN Sunan Ampel, Surabaya, 2018.

. "Fisika Atom sebagai Basis Filosofis Ilmu dalam Perspektif al-Ghazali." Epistemé: Jurnal Pengembangan Ilmu Keislaman 12, no. 1 (2017): 53-75.

N., Syafrial. "Corak Teologi Ibnu Taimiyah”, Tajdid: Jurnal Ilmu-Ilmu Ushuluddin, vol. 18, no. 1. Juli, 2015.

Noorhayati, Siti Mahmudah. "Exclusive Islam From the Perspective of Ibn. alTaymiyah”, Esensia: Jurnal Ilmu-Ilmu Ushuluddin, vol. 18 no. 2. Oktober, 2017.

Rahman, Fazlur. Islam, terj. Senoaji Saleh. Jakarta: Bumi Aksara, 1992.

Shobahussurur, “Proses Pengambilan Keputusan Prespektif Ibn Taimiyah”, Jurnal Tsaqafah, vol.6, no.1. April, 2010.

Yasin, “Pemikiran Hukum Islam Ibnu Taimiyah”, Jurnal IImlah Al-Syir'ah, vol. 8 no. 2. Desember, 2010. 